\title{
Food Preference, Predation Efficiency and Life Table Parameters of Euseius scutalis (Acari: Phytoseiidae) Reared on Tenuipalpus punicae (Acari: Tenuipalpidae) and Siphoninus phillyreae (Hemiptera: Aleyrodidae) Under Constant Conditions
}

\author{
Abdelgayed, A.S. ${ }^{1 *}$, N.M. Abd El-Wahed ${ }^{1}$, A.M. Ali ${ }^{2}$ and S.A. Eraky ${ }^{2}$ \\ ${ }^{1}$ Plant Protection Research Institute, Department of Fruit Acarology, Agricultural \\ Research Center, Dokki 12611 Giza, Egypt. \\ ${ }^{2}$ Plant Protection Department, Faculty of Agriculture, Assiut University, \\ Assiut 71526 Egypt.
}

\begin{abstract}
The biology, life table parameters and predation efficiency of the predatory mite, Euseius scutalis (Acari: Phytoseiidae) feed Tenuipalpus punicae mobile stages and Siphoninus phillyreae eggs were tested at constant conditions $\left(30 \pm 1^{\circ} \mathrm{C} \& 65 \pm 5 \%\right.$ R.H.). The predator completed its developmental times on both prey pests in 6.20 and 6.45 days. The mite was slightly influenced by the prey type, as when fed $T$. punicae mobile stages, its developmental time were shorter than preyed on S. phillyreae eggs. Whenever, the female predator fed the mite mobile stages, the finite rate of increase $(\lambda)$ was higher than that on the insect eggs. The mean generation time $(T)$ was also affected, whereas it was longer when the female preyed on S. phillyreae eggs compared with that on $T$. punicae mobile stages. The E. scutalis female consumed high number of insect eggs during its oviposition period and the longevity was longer in comparison with feed T. punicae mobile stages.
\end{abstract}

Keywords: Predator; Biology; Pomegranate whitefly; Egypt.

\section{Introduction}

Mites of family Phytosiidae Berlese (Mesostigmata) play as a plant inhabiting predator of agricultural arthropod pests, and are recognised as effective natural enemies and potential as biological control candidates (Gerson et al., 2003; McMurtry et al., 2013, 2015; Hoy, 2016; Yang et al., 2019). This family currently is comprising of more than 2798 described species (Demite et al., 2014, 2020). However, several phytoseiid species have been

\footnotetext{
*Corresponding author: Abdelgayed, A.S.

Email: ahmed.abdelgid@yahoo.com

Tel.: +01126590172

Received: October 6, 2020.

Accepted: December 9, 2020.

Published: December 26, 2020.
}

commercially produced in different continent (Van Lenteren, 2012). But many other practical useful phytoseiids remain to be discovered yet to be conducted around the glob to be used for the biological control of pest species. Species of the genus Euseius De Leon are important pollen feeding generalist predators (McMurtry et al., 2013) as they feed several major mite, scale insect and whitefly pests (Nomikou et al., 2001; Raza et al., 2005). Euseius scutalis (Athias-Henriot) was common phytoseiids in Middle East and North Africa (Porath and Swirski, 1965; Bounfour and McMurtry, 1987; Denmark, 1992; Momen and El-Sawi, 
2008). It is the most dominant predator on economic crops in Egypt (El-Laithy and Fouly, 1992; Abou-Awad et al., 2010; Mohamed and Nabil, 2014; Abdelgayed et al., 2017; Marei et al., 2020). The pomegranate false red mite, Tenuipalpus punicae Pritchard and Baker and the pomegranate whitefly, Siphoninus phillyreae (Haliday) are reported to be important pests on pomegranate orchards that cause heavy defoliation; fruits dropping and even death of trees, especially when trees are stressed (Jeppson et al., 1975; Emmanouel and Papadoulis, 1987). Up to date control studies have used phytoseiids, because of their control efficiency to keep numbers of certain pests at low populations (McMurtry and Croft, 1997). Thus, the present work aimed to test the food preference, reproductive performance, predation efficiency and life table parameters of $E$. scutalis feed T. punicae and S. phillyreae to determine the development and behaviour of such predator at constant conditions $\left(30 \pm 1{ }^{\circ} \mathrm{C} \& 65 \pm 5 \%\right.$ R.H. $)$.

\section{Materials and Methods}

\section{Rearing the predatory mite, Euseius scutalis (Athias-Henriot):}

The predatory mite, E. scutalis was collected from pomegranate trees (Punica granatum L., Lythraceae). In the pomology farm, Faculty of Agriculture, Assiut University, $27^{\circ} 02^{\prime} 28.20^{\prime \prime} \mathrm{N}, 31^{\circ}$ 00 ' 25.80" E. Infested bean leaves with T. punicae were provided daily to the stock colony of the predator as a fresh food. The stock colony was maintained under controlled conditions $\left(30 \pm 1{ }^{\circ} \mathrm{C} \&\right.$ $65 \pm 5 \%$ R.H). Inside an incubator. Few drops of water were added when needed.
The pomegranate false red mite, Tenuipalpus punicae Pritchard and Baker:

Individuals of $T$. punicae were collected from fruits and leaves of pomegranate orchards daily and used as a fresh food for the predator in all experiments. The total number of consumed mobile stages by the predator was recorded daily.

The pomegranate whitefly, Siphoninus phillyreae (Haliday):

Infested pomegranate leaves with the pomegranate whitefly were collected. The infested leaves were put in paper bags, then transferred to the laboratory for direct examination under a stereomicroscope. This experiment was conducted under controlled conditions $\left(30 \pm 1^{\circ} \mathrm{C} \& 65 \pm 5 \%\right.$ R.H.). Inside an incubator. The experimental unit consisted of moistened cotton pads placed upon sponges in petri dish $(15 \mathrm{x}$ $20 \mathrm{~cm}$ in diameter). The castor bean, Ricinus communis L. (Euphorbiaceae) leaf discs ( $3 \mathrm{~cm}$ in diameter) were placed upon the cotton pads. A few drops of water were added when needed to keep moisture prevent mite escaping.

The effect of the two prey species and the consumption rates on the development of $\boldsymbol{E}$. scutalis:

Four groups of 35 newly deposited eggs of $E$. scutalis were singly put on arena (3 $\mathrm{cm}$ leaf disc). Siphoninus phillyreae eggs and $T$. punicae mobile stages were used as source of prey. The developmental stages and the number of consumed prey (eggs or mobile stages) were recorded twice daily until the predator reached adulthood. The female predator was mated with the male for one day. Each 
replicate was examined daily to record number of eggs laid and number of consumed prey until the death of the female predator. The leaf discs in each arena were checked each two days. Prey eggs or mobile stages were replaced daily with freshly ones.

\section{Life tables:}

Newly E. scutalis mated female was placed singly in an arena. Predator eggs were collected daily and reared until reaching the adulthood. The sex ratio of the predator was recorded visually. The life table of the predator was recorded using data obtained from the developmental time of immature and adult stages. These experiments were carried out under controlled conditions (temperature and photoperiod).

\section{Statistical analysis:}

Data of the developmental time, longevity and fecundity were subjected to One-way ANOVA (F-test), followed by Duncan's Multiple Range Test ( $\mathrm{P} \leq$ 0.05). (Duncan, 1955) in the programme to determine the difference between means.

Life table parameters were calculated according to (Birch, 1948) using Life 48:

A BASIC computer program (AbouSetta et al., 1986).

The net reproductive rate $\left(R_{0}=\right.$ females/female/generation); intrinsic rate of natural increase $\left(r_{m}=\right.$ females/female/day) and mean generation time $\left(T_{0}=\right.$ in $\left(R_{0} / r\right)$, in days) were estimated (Laing, 1968). After $\left(r_{m}\right)$ was computed for the original data $\left(r_{a 11}\right)$, the differences in $\left(r_{m}\right)$ values were tested for significance by estimating the variance using the Jack knife method to calculate the standard errors.

The Jack-knife pseudo value ( $r j$ ) was calculated for the $n$ samples by using the following equation (Sokal and Rolf, 1981; Krebs, 1998): $r j=n \times r_{a 11}-$ $(n-1) \times r_{i}$. The mean values of $(n-1)$; jack-knife pseudo-values for the mean growth rates in each treatment were subjected to analysis of variance followed by Duncan's Multiple Range Test $(\mathrm{P} \leq 0.01)$. All mentioned analyses were conducted using SAS statistical software (SAS institute, 2010).

\section{Results and discussion}

\section{Developmental time of the predator, Euseius scutalis:}

The Euseius scutalis was completed its development on both $T$. punicae mobile stages and $S$. phillyreae eggs under constant conditions $\left(30 \pm 1{ }^{\circ} \mathrm{C} \& 65 \pm\right.$ $5 \%$ R.H.). The life cycle time (egg to adult) of both sexes was slightly affected by prey type (Table 1). The incubation period of eggs lasted from 1.67 to 1.96 days. The female and male larva lasted respectively $2.28 \& 2.21$ and $2.50 \&$ 2.26 days when fed $T$. punicae mobile stages and S. phillyreae eggs. The female protonymph and deutonymph lasted respectively $1.93 \& 2.04$ and $2.00 \&$ 2.21 days when fed the same previous prey species. While, the male (protonymph and deutonymph) lasted respectively $1.83 \& 1.89$ and $1.50 \&$ 1.59 days. The total developmental period of the predator female was slightly longer when fed $T$. punicae mobile stages than $S$. phillyreae eggs. Momen and El-Sawi (2008); Adly (2016) and Yang et al. (2019) indicated that the developmental periods of $E$. 
scutalis females and males were significantly affected by the prey type, as this period was shorter when it fed Tetranychus urticae Koch eggs than Bemisia tabaci (Gennadius) eggs and instars.

The life cycle averaged respectively 8.17 $\& 8.42$ and $7.5 \& 7.63$ days for female and male when fed both prey species. Fouly et al. (2013) recorded that life cycle of $E$. scutalis lasted an average of $5.20 \& 6.19,6.40 \& 7.23$ and $7.30 \&$ 7.85 days for both male and female when fed pollen grains, $T$. urticae and $B$. tabaci, respectively. Therefore, B. tabaci gave the longest life cycle followed by the two-spotted spider mites, while palm pollen gave the shortest one. El-Laithy and Fouly (1992) recorded that, life cycle of E. scutalis lasted 7.81 and 6.8 days for female and male when fed $T$. urticae. Similar results were observed with shorter times (4.2 days), when $E$. scutalis fed Panonychus citri (McGregor) mobile stages (Kasap and Şekeroğlu, 2004).

The mean number of eggs laid by $E$. scutalis single female mated for one day was respectively 19.38 and 16.85 eggs, when fed $S$. phillyreae eggs and $T$. punicae mobile stages, with an average of 2.05 and 1.97 eggs/day on both pests.

Life table parameters of $E$. scutalis feed $S$. phillyreae and $T$. punicae:

Data in (Table $2 \&$ Figure 1) showed life table parameter and sex ratio of $E$. scutalis fed $S$. phillyreae eggs and $T$. punicae mobile stages. The population doubling time $(D T)$ was longer when the predator fed $S$. phillyreae eggs (3.85 days) than $T$. punicae mobile stages (3.76 days). The finite rate of increase $(\lambda)$ were respectively 1.20 and 1.19 when the predator female fed $T$. punicae mobile stages and $S$. phillyreae eggs. The mean generation time $(T)$ of $E$. scutalis was insignificantly affected by prey type, as $S$. phillyreae eggs gave slightly longer $(T)$ time (12.62 days) compared with (12.19 days) on $T$. punicae mobile stages. The gross reproductive rate $(G R R)$ was respectively 19.79 and $16.52 \mathrm{egg} / \mathrm{female} / \mathrm{generation}$, when the predator fed both $S$. phillyreae eggs and $T$. punicae mobile stages.

Those results are in agreement with Kasap and Șekeroğlu (2004); Fouly et al. (2013) who suggested that the mean generation time $(T)$ of E. scutalis at 26 ${ }^{\circ} \mathrm{C}$ and $70 \%$ R.H. was affected by diet, whereas palm pollen gave the shortest generation time (12.39 days) in comparison with B. tabaci (14.91 days); the intrinsic rate of natural increase $\left(r_{m}\right)$ and the finite rate of increase $\left(r_{m}\right)$ averaged 0.232-1.26, 0.191-1.21 and 0.175-1.91 when E. scutalis fed palm pollen, $T$. urticae and $B$. tabaci, respectively. For instance, Nomikou et al. (2001) showed that $\left(r_{m}\right)$ of E. scutalis fed on Panonychus citri averaged 0.230.29 according to the temperature. Also, Kasap (2004) recorded that $\left(r_{m}\right)$ value of E. scutalis fed on $P$. citri was between 0.16 and 0.29 by increasing temperature, While Momen and El-Sawi (2008) stated that $\left(r_{m}\right)$ value did not exceed 0.14 when the same predatory fed on eggs of cotton leaf worm. However, Al-Shammery (2010) and Osman et al. (2013) reported that $\left(r_{m}\right)$ value of E. scutalis was 0.220 and 0.229 when reared on T. urticae.

\section{Predation efficiency of Euseius scutalis adult and mobile stages:}

The average numbers of consumed $T$. 
punicae mobile stages by E. scutalis larval, protonymphal and deutonymphal stages at $\left(30 \pm 1{ }^{\circ} \mathrm{C} \& 65 \pm 5 \%\right.$ R.H. $)$ were respectively $3.93,5.30 \& 7.04$ and $3.50,4.83 \& 8.67$ individuals for female and male. While those on $S$. phillyreae eggs were respectively $3.28,5.76 \&$ 13.40 and 4.00, $6.00 \& 9.71$ for both sexes. E. scutalis adult female consumed higher number of prey during its oviposition time (64.32 S. phillyreae eggs), with total number of 136.60 consumed eggs during its life span. While those on T. punicae mobile stages were respectively 52.37 and 102.63 individuals. The total prey consumption for male during its life span was respectively 87.43 eggs and 60.83 individuals (Table 3 ).

Table (1): Mean durations (days $\pm \mathrm{SD})$ of E. scutalis reared on two prey species at $\left(30 \pm 1^{\circ} \mathrm{C}, 65 \pm 5 \%\right.$ R.H.)

\begin{tabular}{|c|c|c|c|c|c|c|c|}
\hline \multirow[b]{2}{*}{$\begin{array}{l}\text { Developmental } \\
\text { stage }\end{array}$} & \multicolumn{2}{|c|}{ S. phillyreae } & \multicolumn{2}{|c|}{ T. punicae } & \multirow{2}{*}{$\begin{array}{c}\text { F- } \\
\text { value }\end{array}$} & \multirow{2}{*}{$\begin{array}{c}\mathrm{P}- \\
\text { value }\end{array}$} & \multirow[t]{2}{*}{ L.S.D } \\
\hline & q & 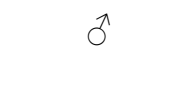 & q & o & & & \\
\hline Egg & $1.96 \pm 0.75 \mathrm{a}$ & $1.89 \pm 0.85 \mathrm{a}$ & $1.96 \pm 0.73 a$ & $1.67 \pm 0.76 \mathrm{a}$ & 0.79 & 0.503 & 0.43 \\
\hline Larva & $2.21 \pm 0.51 \mathrm{a}$ & $2.26 \pm 0.71 \mathrm{a}$ & $2.28 \pm 0.58 \mathrm{a}$ & $2.50 \pm 0.78 \mathrm{a}$ & 0.95 & 0.421 & 0.36 \\
\hline Protonymph & $2.04 \pm 0.36 \mathrm{a}$ & $1.89 \pm 0.85 a$ & $1.93 \pm 0.27 \mathrm{a}$ & $1.83 \pm 0.7 \mathrm{a}$ & 0.53 & 0.664 & 0.33 \\
\hline Deutonymph & $2.21 \pm 0.59 \mathrm{a}$ & $1.59 \pm 0.50 b$ & $2.00 \pm 0.68 \mathrm{a}$ & $1.50 \pm 0.51 b$ & 8.40 & 0.0001 & 0.32 \\
\hline Immature stages & $6.46 \pm 1.06 \mathrm{a}$ & $5.74 \pm 1.06 \mathrm{~b}$ & $6.20 \pm 1.03 \mathrm{ab}$ & $5.83 \pm 1.37 \mathrm{ab}$ & 2.16 & 0.047 & 0.63 \\
\hline Life cycle & $8.42 \pm 1.02 \mathrm{a}$ & $7.63 \pm 1.62 \mathrm{ab}$ & $8.17 \pm 1.10 \mathrm{ab}$ & $7.50 \pm 1.53 b$ & 2.59 & 0.057 & 0.74 \\
\hline Generation & $10.46 \pm 1.35 \mathrm{a}$ & . & $10.24 \pm 1.30 \mathrm{a}$ & . & 0.34 & 0.560 & 0.74 \\
\hline Pre-oviposition & $2.04 \pm 0.81 \mathrm{a}$ & . & $2.07 \pm 0.73 \mathrm{a}$ & . & 0.02 & 0.081 & 0.43 \\
\hline Oviposition & $9.96 \pm 2.66 a$ & . & $8.74 \pm 1.68 \mathrm{a}$ & . & 3.91 & 0.053 & 1.23 \\
\hline Post-oviposition & $2.83 \pm 0.82 \mathrm{a}$ & . & $3.19 \pm 0.74 \mathrm{a}$ & . & 2.62 & 0.112 & 0.43 \\
\hline Longevity & $14.83 \pm 2.63 \mathrm{a}$ & $11.93 \pm 1.84 b$ & $14.00 \pm 1.57 \mathrm{a}$ & $11.83 \pm 1.99 b$ & 13.76 & 0.0001 & 1.12 \\
\hline Fecundity & $19.38 \pm 5.69 a$ & . & $16.85 \pm 5.89 a$ & . & 2.40 & 0.127 & 3.27 \\
\hline Daily rate & $2.05 \pm 0.76 \mathrm{a}$ & . & $1.97 \pm 0.70 \mathrm{a}$ & . & 0.16 & 0.686 & 0.41 \\
\hline Life span & $23.25 \pm 2.91 \mathrm{a}$ & $19.56 \pm 3.34 b$ & $22.17 \pm 1.74 \mathrm{a}$ & $19.33 \pm 3.47 b$ & 10.90 & 0.0001 & 1.63 \\
\hline
\end{tabular}

The means are followed by different letters in the same rows are significantly divergent $(P<0.05$, Duncan). 
Table (2): Life table parameters of E. scutalis reared on S. phillyreae and T. punicae at (30 \pm $1^{\circ} \mathrm{C}, 65 \pm 5 \%$ R.H.)

\begin{tabular}{|c|c|c|}
\hline Parameter & S. phillyreae & T. punicae \\
\hline Mean generation time $\left(T_{c}\right)^{\mathrm{a}}$ & 12.62 & 12.19 \\
\hline Doubling time $(D T)^{\mathrm{a}}$ & 3.85 & 3.76 \\
\hline Net reproductive rate $\left(R_{0}\right)^{\mathrm{b}}$ & 9.82 & 9.47 \\
\hline Intrinsic rate of increase $\left(r_{m}\right)^{\mathrm{c}}$ & 0.180 & 0.184 \\
\hline Finite rate of increase $(\lambda)^{c}$ & 1.19 & 1.20 \\
\hline Gross reproduction rate $(G R R)^{\mathrm{b}}$ & 19.79 & 16.52 \\
\hline $50 \%$ mortality $^{a}$ & 17 & 16 \\
\hline Survival rate $\%$ & 0.75 & 0.70 \\
\hline Sex ratio ( $/$ /total) & 0.70 & 0.80 \\
\hline
\end{tabular}

${ }^{\mathrm{a} D a y s,}{ }^{\mathrm{b}}$ per generation, ${ }^{\mathrm{c}}$ Individuals/female/day

$R_{0}=\Sigma\left(1_{\mathrm{x}} \times \mathrm{m}_{\mathrm{x}}\right) ; T=\Sigma\left(\mathrm{x} \times \mathrm{1}_{\mathrm{x}} \times \mathrm{mx}\right) / \Sigma\left(\mathrm{l}_{\mathrm{x}} \times \mathrm{m}_{\mathrm{x}}\right) ; r_{m}=\ln \left(R_{0}\right) / T ; \mathrm{DT}=\ln (2) / r_{m}$ and $\lambda=\exp \left(r_{m}\right)$.

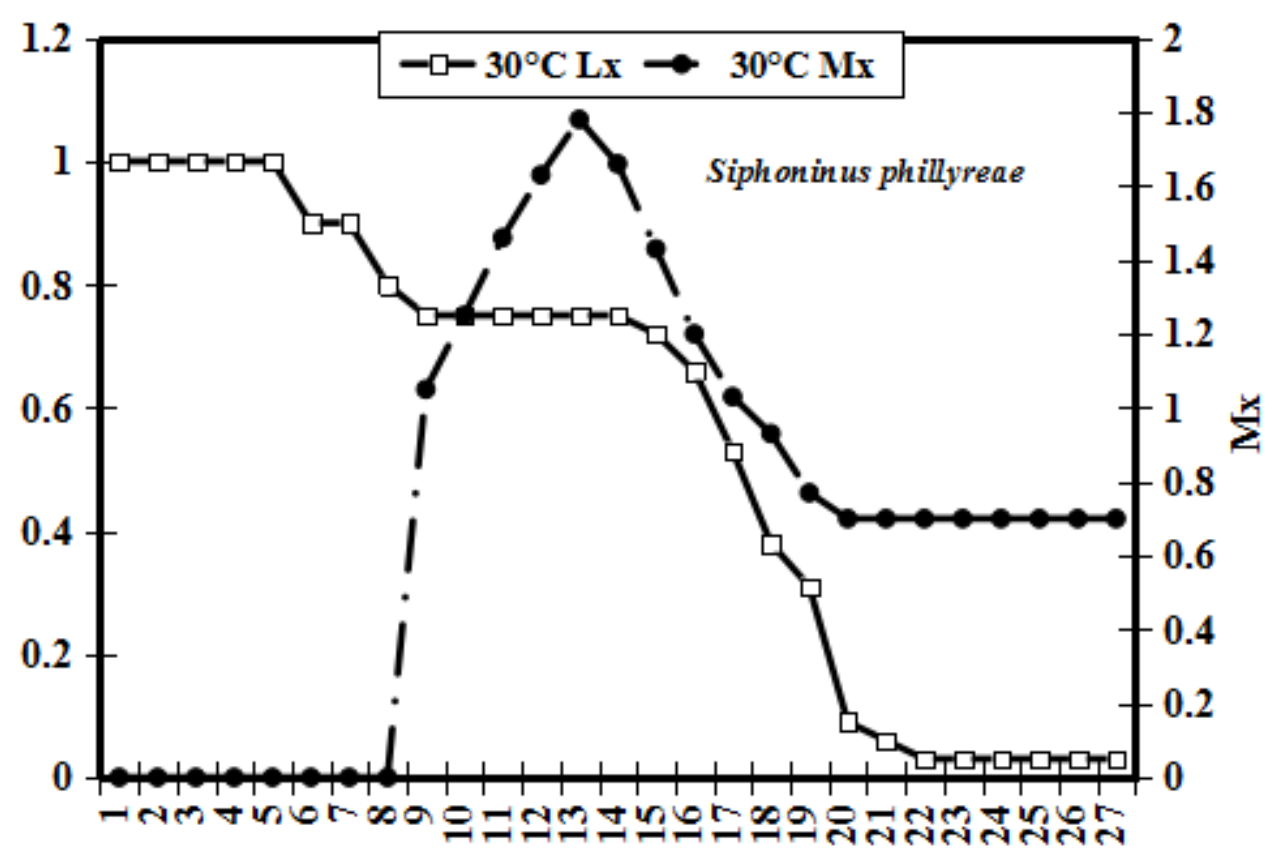




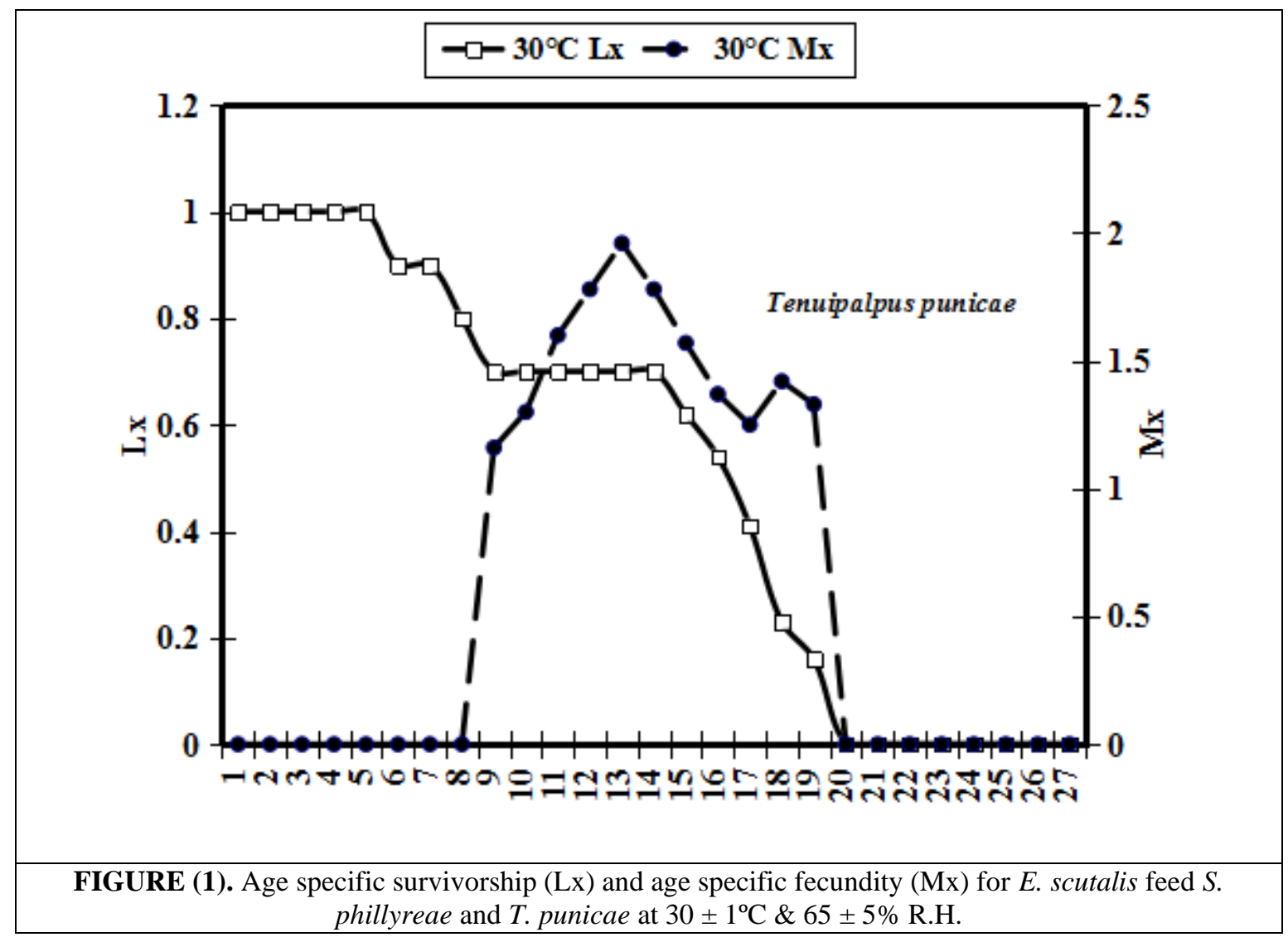

Table (3): Number of consumed preys (Mean \pm S.D.) by E. scutalis reared on S. phillyreae and T. punicae at $\left(30 \pm 1^{\circ} \mathrm{C}, 65 \pm 5 \%\right.$ R.H. $)$

Stages Female ㅇ

$\begin{array}{lcccc}\text { Larva } & 3.28 \pm 1.46 \mathrm{a} & 3.93 \pm 1.17 \mathrm{a} & 0.74 & 3.12 \\ \text { Protonymph } & 5.76 \pm 2.42 \mathrm{a} & 5.30 \pm 2.64 \mathrm{a} & 1.41 & 0.48 \\ \text { Deutonymph } & 13.40 \pm 5.52 \mathrm{a} & 7.04 \pm 4.67 \mathrm{~b} & 2.84 & 20.23 \\ \text { Pre-oviposition } & 25.36 \pm 5.74 \mathrm{a} & 15.30 \pm 4.56 \mathrm{~b} & 2.87 & 49.3 \\ \text { Oviposition } & 64.32 \pm 17.92 \mathrm{a} & 52.37 \pm 16.46 & 9.57 & 6.28 \\ \text { Post-oviposition } & 24.48 \pm 5.56 \mathrm{a} & 18.70 \pm 4.37 \mathrm{~b} & 2.77 & 17.49 \\ \text { Life span } & 136.60 \pm 22.16 \mathrm{a} & 102.63 \pm 15.63 \mathrm{~b} & 10.62 & 41.30 \\ & & \text { Male } \widehat{0} & & \\ \text { Larva } & 4.00 \pm 1.0 \mathrm{a} & 3.50 \pm 1.87 \mathrm{a} & 1.79 & 0.38 \\ \text { Protonymph } & 6.00 \pm 1.63 \mathrm{a} & 4.83 \pm 3.31 \mathrm{a} & 3.10 & 0.68 \\ \text { Deutonymph } & 9.71 \pm 5.71 \mathrm{a} & 8.67 \pm 5.16 \mathrm{a} & 6.69 & 0.12 \\ \text { Life span } & 87.43 \pm 10.53 \mathrm{a} & 60.83 \pm 15.66 \mathrm{~b} & 16.06 & 13.28\end{array}$

Means within rows followed by the same letter were not significantly different at the $5 \%$ level. 


\section{Conclusion}

From the obtained results, it can be suggested that the phytoseiid, Euseius scutalis plays an important role as one of the natural control agents for its ability to control different arthropod pests.

\section{Acknowledgments}

\section{References}

Abdelgayed, A.S., Negm, M.W., Eraky, S.A., Helal, T.Y. and Moussa, S.F.M. (2017) 'Phytophagous and predatory mites inhabiting citrus trees in Assiut Governorate, Upper Egypt 'Assiut Journal of Agricultural Sciences, 48(1), 173-181.

Abou-Awad, B.A., Metwally, A.M. and Al-Azzazy, M.M. (2010) 'Typhlodromips swirskii (Acari: Phytoseiidae) a predator of eriophyid and tetranychid mango mites in Egypt' Acta Phytopathologica et Entomologica Hungarica, 45(1), 135-148.

Abou-Setta, M.M., Sorrell, R.W. and Childers, C.C. (1986) 'Life 48: a BASIC computer program to calculate life table parameters of an insect or mite species' Florida Entomologist, 69, 690697.

Adly, D. (2016) 'Use of predators for controlling the whitefly, Bemisia tabaci Genn., and the two spotted spider mite, Tetranychus urticae Koch., in Cucumber Greenhouses in Egypt' Egyptian Journal of Biological Pest Control, 26(4), 701-706.

Al-Shammery, K.A. (2010) 'Different biological aspects of the predaceous mite Euseius scutalis (Acari: Gamasida: Phytoseiidae) and the effects due to feeding on three tetranychid mite species in Hail, Saudi Arabia' Asian Journal
Special thanks are to Dr. M.M. AbouSetta (Plant Protection Research Institute, Agricultural Research Centre, Dokii, Giza, Egypt) for valuable comments on early versions of this manuscript. Deep thanks also are to Dr. A.S. El-Halawany (Plant Protection Research Institute, Agricultural Research Centre, Dokii, Giza, Egypt) for his help in statistical analysis.

of Biological Sciences, 3(2), 7784.

Bounfour, M. and McMurtry, J.A. (1987) 'Biology and ecology of Euseius scutalis (Athias-Henriot) (Acarina: Phytoseiidae)

Hilgardia, 55(5), 23 pp.

Birch, L.C. (1948) The intrinsic rate of natural increase of an insect population' Journal of Animal Ecological, 17, 15-26.

Demite, P.R., McMurtry, J.A. and Moraes, G.J. de. (2014) 'Phytoseiidae Database: a website for taxonomic and distributional information on phytoseiid mites (Acari)' Zootaxa, 3795(5), 571577.

Demite, P.R., Moraes, G.J. de, McMurtry, J.A., Denmark, H.A. and Castilho, R.C. (2020) 'Phytoseiidae Database' Available from:

www.lea.esalq.usp.br/phytoseiidae (last access 01/08/2019).

Denmark, H.A. (1992) 'Two new species of Typhlodromus (Acari: Phytoseiidae) from North Africa' Israel Journal of Entonology, 2526.

Duncan, D.B. (1955) 'Multiple range and multiple F-test 'Biometrics, 11(1), 1-42.

El-Laithy, A.Y.M. and Fouly, A.H. (1992) 'Life table parameters of the two phytoseeid predators Amblyseius scutalis (AthiasHenriot) and A. swirskii A.-H. 
(Acari, Phytoseiidae) in Egypt' Journal and Applied of Entomology, (113), 8-12.

Emmanouel, N.G. and Papadoulis, G. Th. (1987) 'Panonychus citri (McGregor) (Acarina: Tetranychidae) and Eriophyes madicaginis K. (Eriophyidae): two important phytophagous mites recorded for the first time in Greece' Journals of Entomologia Hellenica, 5, 3-6.

Fouly, A.H.; Nassar, O.A. and Osman, M.A. (2013) 'Biology and life table of Euseius scutalis (A.-H.) reared on different kinds of food' Journal of Entomology, 10, 199206.

Gerson, U., Smiley, R.L. and Ochoa, R. (2003) 'Mites (Acari) for Pest Control' Blackwell Science Ltd, UK, $539 \mathrm{pp}$.

Hoy, M.A. (2016) 'Agricultural acarology: introduction to integrated mite management' USA, Florida, Boca Raton, CRC press, $430 \mathrm{pp}$.

Jeppson, L.R., Keifer, H.H. and Baker, E.W. (1975) 'Mites Injurious to Economic Plants 'University of California Press, Berkeley, CA. USA, 681pp.

Kasap, I. (2004) 'Effect of different apple cultivars and of temperatures on biology and life table parameters of two spotted spider mite, Tetranychus urticae Koch (Acarina: Tetranychidae)' Phytoparasitica, 32, 73-82.

Kasap, I. and Șekeroğlu, E. (2004) ‘ Life history of Euseius scutalis feeding on citrus red mite Panonychus citri at various temperatures , BioControl, 49, 645-654.

Krebs, C.J. (1998) 'Ecological Methodology

Benjamin/Cumming, Menlo Park, CA, $620 \mathrm{pp}$.

Laing, J.E. (1968) 'Life history and life table of Phytoseiulus persimilis
Athias-Henriot ' Acarologia, 10, 578-588.

Marei, F.A., Negm, M.W., Nasser, M.A. and Eraky, S.A. (2020) 'Population dynamics of Oligonychus mangiferus and Aceria mangiferae (Acari: Tetranychidae, Eriophyidae) on two mango cultivars in Assiut Governorate, with an annotated checklist of mango mites in Egypt' International Journal of Entomology and Nematology, 6(1), 149-155.

McMurtry, J.A. and Croft, B.A. (1997) 'Life-styles of Phytoseiid mites and their roles in biological control' Annual Review of Entomology, 42, 291-321.

McMurtry, J.A., Famah Sourassou, N. and Demite, P.R. (2015) 'The Phytoseiidae (Acari: Mesostigmata) as biological control agentes ' In: Carrilo, D., Moraes, G.J. de \& Peña, J.E. (eds.) Prospects for Biological Control of Plant Feeding Mites and Other Harmful Organisms Cham (CH): Springer International Publishing. pp. 133149.

McMurtry, J.A., Moraes, G.J. de and Famah Sourassou, N. (2013) 'Revision of the lifestyles of phytoseiid mites (Acari: Phytoseiidae) and implications for biological control strategies Systematic and Applied Acarology, 18(4), 297-320.

Mohamed, O.M.O. and Nabil, H.A. (2014) 'Survey and biological studies on mite species and scale insects inhabiting mango trees at Sharkia Governorate, Egypt , Journal of Entomology, 11(4), 210-217.

Momen, F.M. and El-Sawi, S. (2008) 'Life-history traits of the predacious mite Euseius scutalis (Athias-Henriot) (Acari: Phytoseiidae) on eggs of three 
insects (Lepidoptera: Noctuidae)'

Acta Phytopathologica et Entomologica Hungarica, 43(1), 163-170.

Nomikou, M., Janssen, A., Schraag, R. and Sabelis, M.W. (2001) 'Phytoseiid predators as potential biological control agents for Bemisia tabaci' Experimental and Applied Acarology, 25, 271-291.

Osman, M.A., Abou-Elella, G.M. and Tawfik, A.A. (2013) 'Temperature dependent development, life table parameters and predation rate of Euseius scutalis (A.-H.) fed on the two-spotted spider mite, Acarines, 7, 11-17.

Porath, A. and Swirski, E. (1965) 'A survey of phytseiid mites (Acarina: Phytoseiidae) on citrus, with description of one new species , Israel Journal of Agricultural Research, 15, 193202.

Raza, A.B.M., Afzal, M. and Bashir, M.H. (2005) 'Biology of Euseius septicus Chaudhari (Acari:
Phytoseiidae) preying on two spotted spider mite, Tetranychus urticae (Acari: Tetranychidae) at different temperature' Parkistan Entomologist, 27, 85-88.

SAS Institute. (2010) 'SAS Statistics and graphicsguide, release 9.1 'SAS Institute, Cary, North Carolina, 27513, USA.

Sokal, R.R. and Rohlf, F.J. (1981) Biometry, $2^{\text {nd }}$ ed. Freeman, New York' Houndmills, Basingstoke RG21 6XS, England, 915 pp.

Van Lenteren, J.C. (2012) 'The state of commercial augmentative biological control: plenty of natural enemies, but a frustrating lack of uptake' BioControl, 57(1), 1-20.

Yang, J., Lv, J., Liu, J., Xu, X. and Wang, E. (2019) 'Prey preference, reproductive performance, and life table of Amblyseius tsugawai (Acari: Phytoseiidae) feeding on Tetranychus urticae and Bemisia tabaci' Systematic and Applied Acarology, 24(3), 404-413. 